\title{
Papers
}

\section{Immunohistochemically detectable p53 and mdm-2 oncoprotein expression in colorectal carcinoma: prognostic significance}

\author{
D Öfner, H Maier, B Riedmann, P Holzberger, M Nogler, M Tötsch, A Bankfalvi, \\ G Winde, W Böcker, K W Schmid
}

\begin{abstract}
Aims-To investigate the correlation between the expression of the p53 and $\mathrm{mdm}-2$ oncoproteins and to assess their prognostic value in colorectal cancer.

Methods-Using a polyclonal (CM1) and a monoclonal antibody directed against p53 and mdm-2, respectively, these oncoproteins were stained immunohistochemically in 109 colorectal adenocarcinomas.

Results-p53 was detected in less than $10 \%$ of tumour cells in 11 of 109 adenocarcinomas, in $10-50 \%$ of tumour cells, in 17 of 109 adenocarcinomas, and in more than $50 \%$ of tumour cells in 32 of 109 adenocarcinomas. Expression of $\mathbf{m d m - 2}$ was detected in 22 of $109(20 \%)$ cases investigated, of which 19 showed concomitant p53 expression. In most cases mdm-2 immunoreactivity was strongly associated with a small proportion of p53 positive tumour cells. Both p53 and mdm2 expression lacked statistical significance when correlated with common staging and grading parameters.

Conclusions-Detection of p53 and mdm2 oncoprotein expression, detected using immunohistochemistry, is of no prognostic value in colorectal cancer. However, the close correlation between $\mathrm{mdm}-2$ immunoreactivity and the proportion of p53 positive cells provides further evidence that the mdm-2 gene product interacts with $\mathbf{p 5 3}$ protein.
\end{abstract}

(f Clin Pathol: Mol Pathol 1995;48:M12-M16)

Keywords: Immunohistochemistry, p53, mdm-2, colorectal cancer.

Somatic mutations of the tumour suppressor gene p53 have attracted much attention as the most common single lesions in human tumours $^{1-3}$ including colorectal cancer. ${ }^{4-8}$ p53 gene mutations are found in $50-70 \%$ of colorectal cancers. The mutant p53 protein has a different conformation to wild-type p53, is more stable and can be detected by immunohistochemistry. In colorectal, ${ }^{69}$ bladder, ${ }^{10}$ and lung cancer ${ }^{11}$ good agreement was found between the frequency of gene mutations and immunohistochemically detectable p53 protein. However, the value of detecting p53 overexpression for the determination of prognosis in colorectal adenocarcinoma is still a matter of debate. ${ }^{12-16}$

Recently, a cellular protein, the murine double-minute-2 (mdm-2) gene product, was shown to complex with wild-type and mutant p53 protein bringing about functional inactivation of the p53 gene. ${ }^{17-19}$ Amplification of this proto-oncogene was detected in sarcomas not carrying p53 mutations ${ }^{19}$ but has not been detected in colorectal carcinoma as yet.

In the present study an immunohistochemical analysis of 109 colorectal adenocarcinomas was performed using a polyclonal p53 antibody (CM1) and a monolonal mdm-2 antibody. The study design was based on recent data suggesting that wild-type $\mathrm{p} 53$ protein may be detectable by immunohisto-chemistry in the presence of the mdm-2 gene product. The immunohistochemical results were compared with the clinical outcome of patients to evaluate the possible prognostic value of detecting one or both oncoproteins.

\section{Methods}

Tumour tissue from 109 consecutive cases of colorectal adenocarcinoma (43 rectal carcinomas and 45 carcinomas of the left and 21 of the right colon; 56 men, 53 women; mean age $67 \cdot 8$ years, range $35-90$ years) was studied. All patients had undergone surgery between 1984 and 1986 at the Department of Surgery I, Innsbruck University Hospital, Austria, either with curative $(n=92)$ or palliative intent $(n=$ 17). Patients who died within 30 days of surgery, with adjuvant chemotherapy and radiotherapy or both, or members of families with familial adenomatosis coli or hereditary nonpolyposis colorectal cancer were excluded from this study.

Tumour tissue was routinely processed, fixed in formalin, embedded in paraffin wax and classified according to Dukes' classification, ${ }^{20}$ with an added D stage for those patients with 


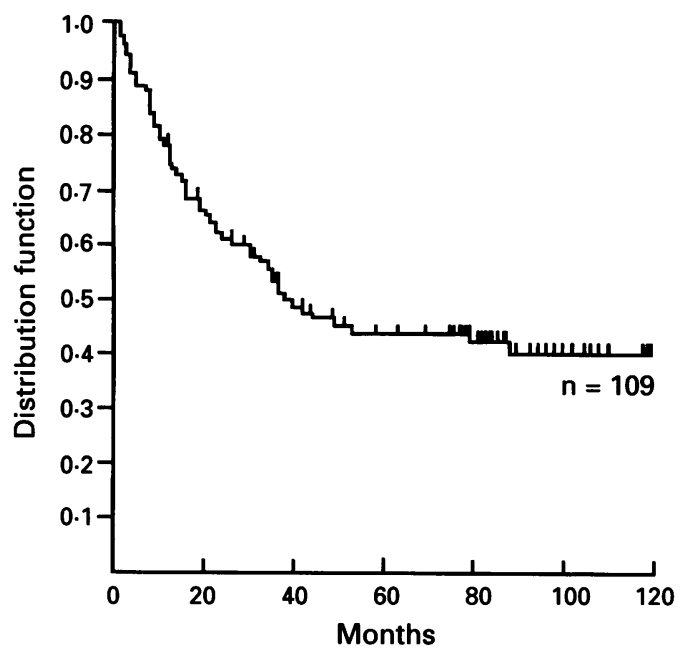

Figure 1 Survival curve (Kaplan-Meier) for all 109 patients investigated in the study.

distant metastases, ${ }^{21}$ the TNM staging system, ${ }^{22}$ and the World Health Organisation (WHO) grading system. ${ }^{23}$ Lymphocytic infiltration at the advancing edge of the tumour was determined according to the criteria outlined by Jass et $a l .^{24} \mathrm{~A}$ detailed description of the staging and grading results is presented in table 1 . Mean follow up was 79 months (fig 1).

For immunohistochemical staining, sections were cut at $2 \mu \mathrm{m}$ and mounted on poly-L-lysine coated glass slides. All sections were dewaxed and rehydrated through a series of graded ethanols. Before staining, sections were pretreated with the wet autoclave method for antigen retrieval for 10 minutes, as described previously. ${ }^{25}$ Incubations with the primary antibodies (polyclonal p53 antibody (CM1; Medac, USA) and monoclonal mdm-2 anti-

Table 1 Frequency of prognostic parameters investigated in 109 colorectal adenocarcinomas

\begin{tabular}{|c|c|c|}
\hline Parameter & Number & Percent \\
\hline \multicolumn{3}{|l|}{ Tumour type } \\
\hline intestinal & 87 & 80 \\
\hline mucinous & 17 & 16 \\
\hline signet ring cell & 5 & 4 \\
\hline \multicolumn{3}{|l|}{ Histological grading } \\
\hline well & 15 & 13 \\
\hline moderate & 69 & 64 \\
\hline poor & 25 & 23 \\
\hline \multicolumn{3}{|c|}{ Lymphocytic infiltration } \\
\hline mild & 43 & 39 \\
\hline moderate & 49 & 45 \\
\hline significant & 17 & 16 \\
\hline \multicolumn{3}{|l|}{ Dukes' stage } \\
\hline A & 11 & 10 \\
\hline B & 48 & 44 \\
\hline $\mathrm{C}$ & 32 & 30 \\
\hline D & 17 & 16 \\
\hline \multicolumn{3}{|l|}{ pT stage } \\
\hline $\mathrm{pT} 1$ & 12 & 11 \\
\hline pT2 & 34 & 31 \\
\hline pT3 & 51 & 47 \\
\hline pT4 & 11 & 10 \\
\hline \multicolumn{3}{|l|}{ pN stage } \\
\hline pN0 & 56 & 51 \\
\hline pN1 & 13 & 12 \\
\hline pN2 & 20 & 18 \\
\hline nP3 & 7 & 6 \\
\hline pNx & 13 & 12 \\
\hline \multicolumn{3}{|l|}{ Tumour site } \\
\hline right hemicolon & 21 & 19 \\
\hline left hemicolon & 45 & 41 \\
\hline rectum & 43 & 40 \\
\hline \multicolumn{3}{|l|}{ Age } \\
\hline$\leqslant 65$ years & 38 & 35 \\
\hline $\begin{array}{l}>65 \text { years } \\
\text { Sex }\end{array}$ & 71 & 65 \\
\hline \multicolumn{3}{|l|}{ Sex } \\
\hline male & 56 & 51 \\
\hline female & 53 & 49 \\
\hline
\end{tabular}

body (Oncogene Science, USA)), the enzyme colour reaction, light haematoxylin counterstaining, and section mounting were carried out as described elsewhere. ${ }^{25}$

Semiquantitative evaluation of $\mathrm{p} 53$ and mdm-2 immunoreactivity was performed by one of the authors (KWS). Immunoreactivity was scored as follows: no immunoreactivity $(-)$; positive staining in less than $10 \%$ of tumour cells $(+)$; positive staining in $10-50 \%$ of tumour cells with a mainly focal distribution $(++)$; positive staining in more than $50 \%$ p53 positive tumour cells $(+++)$.

All data were analysed using the SYSTAT statistical package ${ }^{26}$ including the SURVIVAL supplementary module. ${ }^{27}$ Patients were followed according to the oncological follow up scheme of the Department of Surgery I: patients underwent clinical and laboratory examinations every three months within the first three years, every six months four and five years after surgery, and once a year thereafter. Colonoscopy or barium enema and chest $x$ ray were performed twice a year in the first three years and once a year until five years after surgery. The data concerning the date and cause of death were confirmed by the Österreichisches Statistisches Zentralamt, an Institute of the Austrian government. Cumulative patient survival was estimated using the Kaplan-Meier method ${ }^{28}$; the log rank test was used to compare survival curves (Mantel-Haenszel). ${ }^{29}$ Descriptive statistics for continuous measures are given as the mean (SD); for discrete data, frequency counts and percentages are tabulated and groups were compared using $\chi^{2}$ analysis with Yates' correction where appropriate.

Table 2 Frequencies of p53 scores according to Dukes' Stage

\begin{tabular}{lllll}
\hline P53 & Dukes' $A$ & Dukes' $^{\prime}$ & Dukes' $^{\prime}$ & Dukes' $^{\prime} D$ \\
\hline Negative & 6 & 25 & 10 & 8 \\
+ & 1 & 4 & 5 & 1 \\
++ & 2 & 9 & 4 & 2 \\
+++ & 2 & 11 & 13 & 6 \\
\hline
\end{tabular}

p53 scores: $+=<10 \% ;++=10-50 \% ;+++=>50 \%$.

Table 3 Frequencies of p53 scores according to tumour site

\begin{tabular}{lccc}
\hline p53 & $\begin{array}{l}\text { Proximal } \\
\text { colon }\end{array}$ & $\begin{array}{l}\text { Distal } \\
\text { colon }\end{array}$ & Rectum \\
\hline Negative & 12 & 20 & 17 \\
+ & 2 & 7 & 2 \\
++ & 1 & 8 & 8 \\
+++ & 6 & 10 & 16 \\
\hline
\end{tabular}

p53 scores: $+=<10 \% ;++=10-50 \%,+++=>50 \%$.

Table 4 p53 immunoreactivity with regard to $m d m-2$ scores

\begin{tabular}{llll}
\hline & \multicolumn{3}{l}{$m d m-2$} \\
\cline { 2 - 4 }$p 53$ & Negative & + & ++ \\
\hline Negative $(\mathrm{n}=49)$ & 46 & 3 & 0 \\
$+(\mathrm{n}=11)$ & 1 & 8 & 2 \\
$++(\mathrm{n}=17)$ & 10 & 1 & 6 \\
$+++(\mathrm{n}=32)$ & 30 & 1 & 1 \\
\hline p53 scores: $+=<10 \% ;++=10-50 \% ;+++=>50 \%$. \\
mdm-2 scores: $+=<10 \% ;++=>10 \%$.
\end{tabular}


Table 5 Correlation between p53, mdm-2 scores and the various prognostic parameters investigated

\begin{tabular}{|c|c|c|c|c|c|c|}
\hline \multirow[b]{2}{*}{ Parameter } & \multicolumn{3}{|l|}{$p 53$} & \multicolumn{3}{|c|}{$m d m-2$} \\
\hline & $\chi^{2}$ & $D F$ & $p$ & $\chi^{2}$ & $D F$ & $p$ \\
\hline $\begin{array}{l}\text { M Stage } \\
\text { pN stage* (PN0 vs pN1-3) } \\
\text { Dukes' classification } \\
\text { pT stage } \\
\text { Tumour site } \\
\text { Lymphocytic infiltration } \\
\text { Tumour type } \\
\text { Histological tumour grade } \\
\text { Age ( } \leqslant 65 v>65 \text { years) } \\
\text { Sex }\end{array}$ & $\begin{array}{l}0 \cdot 6 \\
1.5 \\
1 \cdot 2 \\
3 \cdot 0 \\
3 \cdot 9 \\
0 \cdot 9 \\
1 \cdot 3 \\
4 \cdot 8 \\
0.02 \\
1.9\end{array}$ & $\begin{array}{l}1 \\
1 \\
3 \\
3 \\
2 \\
2 \\
2 \\
2 \\
1 \\
1\end{array}$ & $\begin{array}{l}\text { NS } \\
\text { NS } \\
\text { NS } \\
\text { NS } \\
\text { NS } \\
\text { NS } \\
\text { NS } \\
\text { NS } \\
\text { NS } \\
\text { NS }\end{array}$ & $\begin{array}{l}0 \cdot 9 \\
2 \cdot 0 \\
4 \cdot 0 \\
3 \cdot 9 \\
4 \cdot 0 \\
7 \cdot 7 \\
3 \cdot 3 \\
2 \cdot 1 \\
0 \cdot 5 \\
2 \cdot 5\end{array}$ & $\begin{array}{l}2 \\
2 \\
6 \\
6 \\
4 \\
4 \\
4 \\
4 \\
2 \\
2\end{array}$ & $\begin{array}{l}\text { NS } \\
\text { NS } \\
\text { NS } \\
\text { NS } \\
\text { NS } \\
\text { NS } \\
\text { NS } \\
\text { NS } \\
\text { NS } \\
\text { NS }\end{array}$ \\
\hline
\end{tabular}

${ }^{*} \mathrm{pNx}$ cases ( $\mathrm{n}=13$; four with Dukes' A and nine with Dukes' $\mathrm{D}$ cancer) excluded.

Results

Positive p53 stained nuclei were detected in 60 of 109 (55\%) colorectal carcinoma cases. Immunohistochemical staining results with respect to the Dukes' classification are summarised in table 2. Pronounced p53 immunoreactivity $(+++)$ was found in advanced tumour stages (in two of $11(18 \%)$ with Dukes' $A$; in 11 of 49 (22\%) with Dukes' B; in 13 of $32(41 \%)$ with Dukes' C; and in six of 17 (35\%) with Dukes' D cancer) and was accompanied by a slight decrease in the number of totally negative cases. The frequency of p53 negative cases was higher in left sided compared with right sided tumours. None of these comparisons were statistically significant.

Expression mdm-2 was detected using immunohistochemistry in 22 of the $109(20 \%)$ of cases investigated. The $\mathrm{p} 53$ and $\mathrm{mdm}-2$ scores are presented in table 4 . In general, $\mathrm{mdm}-2$ and p53 immunoreactivities were detected in serial sections from the same tumour areas. In three p53 negative cases $\mathrm{mdm}-2$ was detected in less than $10 \%$ of tumour cells. Only one of 11 cases with less than $10 \%$ p 53 positive cells lacked mdm-2 immunoreactivity. Of the 49 cases with $\mathrm{p} 53$ overexpression in more than $10 \%$ of tumour cells $(++/+++)$, nine showed $\mathrm{mdm}-2$ staining. This association was highly statistically significant (total $\chi^{2} 69 \cdot 3$, $\mathrm{DF}=6, \mathrm{p}=0.0001$ ). Comparisons of $\mathrm{p} 53$ and mdm-2 scores with respect to various staging and grading parameters are presented in table 5 .

Results of univariate survival analysis of all parameters investigated are given in table 6 . Kaplan-Meier survival curves with regard to all p53 scores investigated (Mantel-Haenszel: $\chi^{2}$ $3 \cdot 4, \mathrm{DF}=3, \mathrm{NS}$ ) are shown in fig 2 . The survival curve of $\mathrm{mdm}-2$ positive cases was

Table 6 Prognostic factors examined in 109 colorectal carcinomas: a univariate approach to cancer specific mortality

\begin{tabular}{llll}
\hline & $\begin{array}{l}\text { Univariate } \chi^{2} \text { for the } \\
\text { log-rank test }\end{array}$ & DF & \\
\hline Dukes' stage & $88 \cdot 1$ & 3 & $0 \cdot 0001$ \\
pT stage & $17 \cdot 7$ & 3 & $0 \cdot 0001$ \\
pN stage* & $25 \cdot 7$ & 3 & $0 \cdot 0001$ \\
Lymphocytic infiltration & $8 \cdot 6$ & 2 & $0 \cdot 01$ \\
Histological tumour grade & $7 \cdot 4$ & 2 & $0 \cdot 02$ \\
p53 scores $(-/+v++/+++)$ & $1 \cdot 5$ & 1 & NS \\
mdm-2 scores (negative $v+/++)$ & $0 \cdot 1$ & 1 & NS \\
Tumour type & $4 \cdot 0$ & 2 & NS \\
Tumour site & $2 \cdot 2$ & 2 & NS \\
Age $(\leqslant 65 v>65$ years) & $0 \cdot 1$ & 2 & NS \\
Sex & $0 \cdot 001$ & 1 & \\
\hline
\end{tabular}

* pNx cases ( $n=13$; four with Dukes' A and nine with Dukes' D cancer) excluded. similar to the survival curve of cases with positive p53 immunoreactivity (Mantel-Haenszel: $\chi^{2}=3 \cdot 7, \mathrm{DF}=2, \mathrm{NS}$ ) (fig 3).

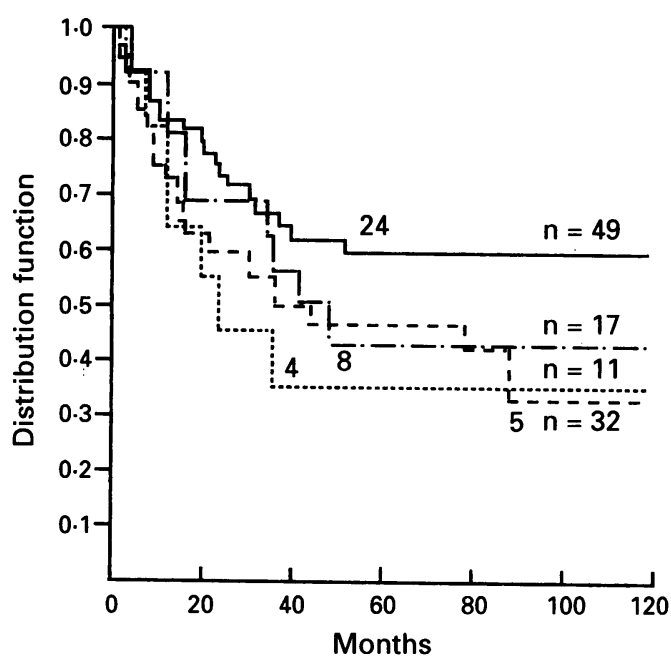

Figure 2 Kaplan-Meier estimations according to immunohistochemically demonstrable p53 expression: negative; -- $<10 \%$; - - - - >10\% to $50 \%$; --$>50 \%$ positive tumour cells for p53 protein (MantelHaenszel: $\chi 2=4 \cdot 3, D F=3, N S$ ). Comparison between p53 negative and p53 positive tumours showed no statistical significance (Mantel-Haenszel: $\chi 2=3 \cdot 4, D F=$ $1, N S)$.

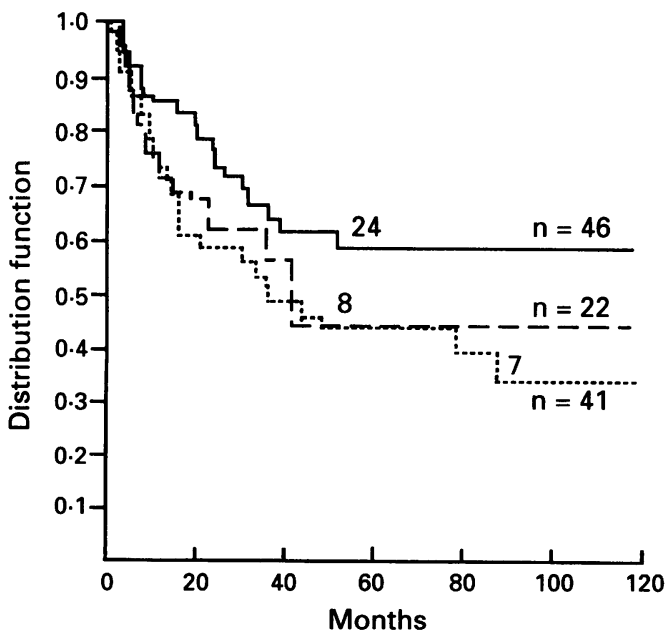

Figure 3 Kaplan-Meier estimations according to immunohistochemical demonstrable p53 and associated mdm-2 staining patterns: - negative for both $p 53$ and $m d m-2$; - - - positive for $m d m-2$ protein; - - - positive for $p 53$ but negative for $m d m-2$ expression (MantelHaenszel: $\chi 2=3 \cdot 7, D F=2$ (NS). 


\section{Discussion}

The extended palette of adjuvant chemotherapy and/or radiotherapy schedules in combination with biological response modifiers requires determination of groups of patients with (morphological) prognostic features which are independent of common staging and grading classifications. Recent advances in the understanding of tumorigenesis of colorectal cancer suggest that p53 tumour suppressor gene dysfunction may play a central role. Therefore, promising results were expected when $\mathrm{p} 53$ abnormalities were evaluated on both the molecular and immunohistochemical level. ${ }^{30}$ Yet only one report dealing with p53 mutations in a large series of sporadic colorectal cancers demonstrated a statistical correlation between p 53 mutation and patient survival. ${ }^{8}$ On the other hand, because of the clearly demonstrated association between increased p 53 protein stability and mutation, ${ }^{6931}$ several immunohistological investigations have been performed previously. In these studies, however, strict correlations between survival and p53 overexpression were not observed. ${ }^{13-16}$

The results of the present study reveal a highly statistically significant $(p=0.0001)$ correlation between immunohistochemically detectable $\mathrm{mdm}-2$ expression and low $(+)$ or moderate $(++)$ p53 overexpression (table 4). Only three of 109 cases $(2 \cdot 8 \%$; two with Dukes' B and one with Dukes' D cancer) showed positive staining for $\mathrm{mdm}-2$ with a concomitant lack of p53 expression. By contrast, two samples $(1 \cdot 8 \%$; one with Dukes' A and one with Dukes' B cancer) classified as strongly $(+++)$ overexpressing p53 also showed mdm-2 positive immunoreactivity. Moreover, the survival curve of $\mathrm{mdm}-2$ positive cases (irrespective of $\mathrm{p} 53$ expression) more closely resembled that of $\mathrm{p} 53$ positive than $\mathrm{p} 53$ negative patients (fig 2 ).

Concerning p 53 frequency distribution and correlations with common prognostic parameters, the findings of the present study confirm those of other investigators. ${ }^{13-16}$ Although not statistically significant, a preponderance of left sided colon cancers with p53 positive immunoreactivity was observed. Furthermore, immunohistochemically detectable p53 was more frequently observed in advanced cancer stages and was associated with poor clinical outcome. All statistical comparisons, including survival analysis, lacked significance. These observations strongly suggest that p53 overexpression in less than $10 \%$ of nuclei probably occurs through complexing with the $\mathrm{mdm}-2$ protein. We did not observe a correlation between immunohistochemically detectable p53 expression and clinical outcome.

Several molecular studies suggest that tumorigenesis in colorectal cancer occurs in a stepwise manner through a series of genetic alterations. ${ }^{3233}$ This study demonstrates that a recently described oncoprotein, the mdm-2 gene product, is expressed in colorectal cancer. Its association with cases showing a small proportion of cells with immunohistochemically detectable p53 expression suggests that the mdm-2 gene may be involved in the auto- regulation of $\mathrm{p} 53$ gene function. These multiple interactions may be responsible for the lack or only marginal value of proto-oncogenes as independent prognostic parameters. Thus, the Dukes' classification, which is easy to reproduce and relates well to survival, still remains the "gold standard" with regard to prognosis in colorectal cancer. Immunohistochemical or genetic, or both, investigations of proto-oncogenes, however, may be useful in helping to understand the biological mechanism(s) underlying this simple and reliable "gold standard".

The authors would like to thank Ms U Neubert, Ms A Muhmann and Ms B Kunk for technical and Mrs H Gerdes-Funnekötter Friedl for prompt and helpful advice.

1 Curtis $\mathrm{CH}$, Hollstein M. Clinical implications of the p53 tumor-suppressor gene. N Engl F Med 1993;329:1318-27.

2 Levine AJ, Perry ME, Chang A, Silver A, Dittmer D, Wu $M$, et al. The 1993 Walter Hubert Lecture: the role of p53 tumour-suppressor gene in tumorigenesis. Brf Cancer p53 tumour-supp

3 Soussi T, Legros Y, Lubin R, Ory K, Schlichtholz B. Multifactorial analysis of $\mathrm{p} 53$ alteration in human cancer: tifactorial analysis of $\mathrm{p} 53$ alteration
review. Int $\mathcal{f}$ Cancer $1994 ; 57: 1-9$.

4 Baker SJ, Fearon ER, Nigro J, Hamilton S, Preisinger AC, Jessup JM, et al. Chromosome 17 deletions and p53 gene mutations in colorectal carcinoma. Science 1989;244: 217-21

5 Baker SJ, Preisinger AC, Jessup JM, Paraskeva C, Markowitz $\mathrm{S}$, Willson JKV, et al. p53 gene mutations occur in combination with $17 \mathrm{p}$ allelic deletions as late events in colorectal tumorigenesis. Cancer Res 1990;50:7717-22.

6 Rodriges NR, Rowan A, Smith MEF, Kerr IB, Bodmer WF, Gannon JV, et al. p 53 mutations in colorectal cancer. Proc Gannon JV, et al. p53 mutations in co
Natl Acad Sci USA 1990;87:7555-9.

8 Shirasawa $S$, Urabe K, Yanagawa Y, Toshitani K, Iwama $T$, Sasazuki T. p53 gene mutations in colorectal tumors from patients with familial polyposis coli. Cancer Res 1991 51:2874-8.

8 Hamelin R, Laurent-Puig P, Olgschwang S, Jego N, Asselain $\mathrm{B}$, Remvikos Y, et al. Association of p 53 mutations with short survival in colorectal cancer. Gastroenterology 1994 106:42-8.

9 Baas IO, Mulder J-WR, Offerhaus GJA, Vogelstein B, Hamilton SR. An evaluation of six antibodies for immunohistochemistry of mutant p53 gene product in munohistochemistry of mutant p53 gene product in

10 Cordon-Cardo C, Dalbagni G, Saez GT, Oliva MR, Zhang Z-F, Rosai J, et al. p53 mutations in human bladder cancer: genotypic versus phenotypic patterns. Int $\mathcal{f}$ Cancer 1994;56:347-53.

11 Bodner SM, Minna JD, Jensen SM, Damico D, Carbone $\mathrm{D}$, Mitsudomi T, et al. Expression of mutant $\mathrm{p} 53$ proteins in lung cancer correlates with the class of $\mathrm{p} 53$ gene mutation. Oncogene 1992;7:743-9.

12 Purdie CA, O'Grady J, Piris J, Wyllie AH, Bird CC. p53 expression in colorectal tumors. Am $\mathcal{F}$ Pathol 1991;138: 807-13.

13 Scott N, Sagar P, Stewart J, Balir GE, Dixon MF, Quirke P. p53 in colorectal cancer: clinicopathological correlation P. p53 in colorectal cancer: clinicopathological correlation

14 Starzynska T, Bromley M, Ghosh A, Stern PL. Prognostic significance of $\mathrm{p} 53$ overexpression in gastric and colorectal cancer. Br $\mathcal{F}$ Cancer 1992;66:558-62.

15 Sun XF, Carstensen JM, Stal O, Zhang H, Nilsson E, Sjodahl $\mathrm{R}$, et al. Prognostic significance of $\mathrm{p} 53$ expression in relation to DNA ploidy in colorectal adenocarcinoma. Virchows Arch A Pathol Anat Histopathol 1993;423:443-8.

16 Yamaguchi A, Nakagawara G, Kurosaka Y, Nishimura G, Yonemura Y, Miyazaki I. p53 immunoreaction in endoscopic biopsy specimens of colorectal cancer, and its prognostic significance. Br f Cancer 1993;68:399-402.

17 Barak Y, Oren M. Enhanced binding of a $95-\mathrm{kDa}$ protein to $\mathrm{p} 53$ in cells undergoing p53-mediated growth arrest. to p53 in cells undergoing

18 Momand J, Zambetti GP, Olson DC, Heorge D, Levine AJ. The $\mathrm{mdm}-2$ oncogene product forms a complex with the p53 protein and inhibits p53-mediated transactivation. Cell 1992;69:1237-45.

19 Oliner JD, Kinzler KW, Meltzer PS, Georges DL, Vogelstein B. Amplification of a gene encoding $\mathrm{p} 53$ associated protein in human sarcomas. Nature 1992;358:80-3.

20 Dukes CE, Bussey HJR. The spread of rectal cancer and its effect on prognosis. Br $\mathcal{f}$ Cancer 1958;12:309-20.

21 Lineweaver W. Staging colon cancer. Contemp Surg 1984; 25:19.

22 Spiessl B, Beahrs OH, Hermanek P, Hutter RVP, Scheibe $\mathrm{O}$, Sobin LH, et al. TNM atlas: illustrated guide to the TNM/pTNM classification of malignant tumors. New York, Berlin, Heidelberg: Springer-Verlag, 1992.

23 Morson BC, Sobin LH. International histological classification of tumours. Geneva: World Health Organisation, 1976. 24 Jass JR, Atkins WS, Cuzick J, Bussey JH, Moson BC 
Northover JM, et al. The grading of rectal cancer: historical perspectives and a multivariate analysis of 447 cases. Histopathology 1986;10:437-59.

25 Bankfalvi A, Navabi H, Bier B, Böcker W, Jasani B, Schmid $\mathrm{KW}$. Wet autoclave pretreatment for antigen retrieval in $\mathrm{KW}$. Wet autoclave pretreatment for antigen retrieval in 26 Wilkinson L. SYSTAT; The system of statistics. Evanston, Illinois: Systat Inc., 1989.

27 Steinberg D, Colla P. Survival: a supplementary to module for SYSTAT. Evanston, Illinois: Systat Inc., 1988

28 Kaplan EL, Meier P. Nonparametric estimation from incomplete observations. $\mathcal{f}$ Am Stat Assoc 1958;53:457-81.
29 Kalbfleisch JD, Prentice RL. The statistical analysis of failure time data. New York: John Wiley and Sons, 1980.

30 Jensen RA, Page DL. p53: the promising story continues to unfold. Mod Pathol 1993;25:455-6.

31 Iggo R, Gatter K, Bartek J, Lane DP, Harris A. Increased expression of mutant forms of $\mathrm{p} 53$ oncogene in primary lung cancer. Lancet 1990; 335:657-9.

32 Fearon ER, Vogelstein B. A genetic model for colorectal tumorigenesis. Cell 1990;61:759-67.

33 Aaltonen LA, Peltomäki P, Leach FS, Sistonen P, Pylkkänen L, Mecklin J-P, et al. Clues to the pathogenesis of familial colorectal cancer. Science 1993;260:812-16. 